\title{
KONVENSI KETATANEGARAAN DALAM SISTEM HUKUM NASIONAL DI INDONESIA PASCA ERA REFORMASI
}

\author{
(Constitutional Convention in Indonesia National Law System After The Reformation)
}

\author{
Ahmad Gelora Mahardika \\ Hukum Tata Negara Institut Agama Islam Negeri Tulungagung \\ Jl. Major Sujadi Timur No.46 Tulungagung \\ Email : geloradika@gmail.com
}

Naskah diterima: 28 Januari 2019; revisi: 25 Februari 2019; disetujui: 19 Maret 2019

\begin{abstract}
Abstrak
Sejak era reformasi, Konvensi ketatanegaraan sebagai hukum tertulis mulai tergerus oleh formalisasi hukum. Hampir semua tradisi bernegara Indonesia saat ini dinormakan dalam bentuk peraturan perundang-undangan. Sebagai salah satu sumber hukum, konvensi seharusnya tetap dipertahankan keberadaannya, meskipun karakteristik itu jarang terjadi di negara civil law. Di Indonesia konvensi perlahan demi perlahan mulai menghilang, dikarenakan semua konvensi cenderung untuk dinormakan dalam peraturan tertulis. Apabila kondisi ini dipertahankan secara terus menerus, konvensi sebagai salah satu sumber hukum akan punah. Penelitian ini menggunakan metoda yuridis normatif, dan menyimpulkan bahwa pembuat undang-undang seharusnya menempatkan posisi konvensi dalam hierarki peraturan perundang-undangan untuk memberikan kepastian hukum atas kedudukan konvensi dalam sistem hukum Indonesia. Artikel ini mencoba untuk melihat posisi konvensi yang tersisa hingga saat ini dalam sistem ketatanegaraan Indonesia, serta bagaimana kita menempatkannya dalam sistem hukum nasional sebagai upaya untuk menjaga tradisi kehidupan ketatanegaraan Indonesia.

Kata kunci : konvensi, norma, praktek, tradisi
\end{abstract}

\begin{abstract}
Since reform era, 'The Constitutional Convention as written constitution began to be eroded by the formalization of the law. Almost all the traditions of the Indonesian constitution are currently formulated in the form of legislationAs one of the sources of law, its existence should be maintained, although this characteristic is rare in a country that adheres to the principle of civil law. In Indonesia this convention slowly began to vanished, because all conventions tended to be regulated in written regulations. If this condition is maintained continuously, the convention as a source of law will become extinct. This research used juridical-normative method and conclude that legislative must place the position of the convention in the hierarchy of legislation to provide legal certainty over the position of the convention in the Indonesian legal system. This article tries to look at the conventions that are left now in the Indonesian constitutional system, and how we place them in the national legal system as an effort to keep tradition in Indonesian constitutional.
\end{abstract}

Keywords : convention, norm, practices, tradition 


\section{A. Pendahuluan}

Dalam negara yang menganut asas common law, konvensi ketatanegaraan adalah sesuatu hal yang lumrah bahkan pada dasarnya hampir semua proses ketatanegaraan tidak diatur dalam undang-undang, akan tetapi hanya diatur oleh konvensi atau kebiasaan ketatanegaraan. ${ }^{1}$ Akan tetapi di negara yang menganut asas civil law, konvensi ketatanegaraan bisa dibilang langka atau keberadaannya tidak ada sama sekali. Hal itu disebabkan segala proses ketatanegaraan di negara yang menganut asas civil law identik dengan norma dalam peraturan perundangundangan. $^{2}$

Konvensi dalam sejarah ketatanegaraan Indonesia ada sejak era kemerdekaan hingga Orde Baru meski jumlahnya tidak terlalu banyak. Akan tetapi, sejak Era Reformasi, jumlah konvensi ketatanegaraan semakin lama semakin berkurang. Hal itu disebabkan karena semua tradisi politik yang sudah berjalan sekian tahun kemudian dinormakan dalam aturan tertulis, seperti pembacaan pidato Presiden setiap tanggal 16 Agustus di depan sidang paripurna DPR. Secara konstitutional, hal tersebut tidak diatur dalam UUD 1945 karena Presiden bertanggung jawab secara langsung kepada rakyat bukan kepada DPR sebagai perwujudan sistem pemerintahan presidensiil murni. Akan tetapi karena ini sudah menjadi kebiasaan ketatanegaraan di Indonesia, proses itu tetap dilakukan setiap tahun dan menjadi tradisi yang wajib dilakukan oleh Presiden setiap tanggal 16 Agustus.

Dalam tradisi negara yang menganut asas civil law, undang-undang merupakan sumber hukum utama. Namun meskipun menggunakan sumber hukum tertulis sebagai rujukan utamanya, negara yang menganut asas civil law kerap kali juga menggunakan putusan pengadilan sebagai salah satu rujukan. Bahkan dalam konteks negara Indonesia, putusan Mahkamah Konstitusi dan Mahkamah Agung kerap kali menjadi rujukan utama dalam pengambilan keputusan. ${ }^{3} \mathrm{Hal}$ ini membuktikan bahwa dalam negara yang menganut asas civil law pun, tradisi-tradisi hukum common law juga turut digunakan.

Sebagai salah satu negara di dunia ini yang menjadikan civil law sebagai sistem hukumnya, Indonesia mempunyai banyak tradisi ketatanegaraan yang cukup panjang. Dahlan Thaib mengemukakan terdapat sejumlah tradisi ketatanegaraan di Indonesia yang tidak dinarasikan dalam aturan tertulis, seperti Praktik di Majelis Permusyawaratan Rakyat (MPR), mengenai pengambilan keputusan berdasarkan musyawarah untuk mufakat atau pidato Presiden setiap tanggal 16 Agustus di depan sidang paripurna MPR. ${ }^{4}$

Kesemua tradisi diatas adalah tradisi ketatanegaraan Indonesia yang berlangsung

$1 \quad$ Menurut Judge Peter J. Messitte adalah suatu kesalahan menyebut bahwa karakteristik common law adalah hukum tidak tertulis (unwritten law). Putusan pengadilan yang diinterpretasikan sebagai hukum kenyataannya selalu tertulis dan mudah diakses. Lihat Judge Peter J.Mesitte, “Common Law V. Civil Law Systems", http://web. ntpu.edu.tw/ markliu/common_v_civil.pdf diakses pada tanggal 27 Januari 2019

2 H. Mustaghfirin, "Sistem Hukum Barat, Sistem Hukum Adat, Dan Sistem Hukum Islam Menuju Sebagai Sistem Hukum Nasional Sebuah Ide Yang Harmoni," Jurnal Dinamika Hukum (2011):91.

3 Oly Viana Agustine, "Keberlakuan Yurisprudensi pada Kewenangan Pengujian Undang-Undang dalam Putusan Mahkamah Konstitusi," Jurnal Konstitusi (2018):647.

4 Tri Suhendra Arbani, "Eksistensi Konvensi sebagai Sumber dan Praktek Ketatanegaraan di Indonesia," Supremasi Hukum (2016):124. 
secara rutin meskipun tidak ada dasar hukum kuat yang mengatur hal tersebut. Akan tetapi sejak era reformasi, hampir semua kebiasaan ketatanegaraan itu dinormakan kedalam peraturan perundang-undangan. Artikel ini mencoba untuk melihat bagaimana posisi konvensi ketatanegaraan Indonesia dalam beberapa tahun belakangan ini serta bagaimana proyeksi kedudukan konvensi ketatanegaraan dalam sistem hukum nasional di masa yang akan datang.

\section{B. Metode Penelitian}

Metode penelitian dalam artikel ini adalah yuridis normatif, yaitu penelitian yang difokuskan untuk mengkaji penerapan kaidah-kaidah atau norma-norma dalam hukum positif. ${ }^{5}$ Penulis mencoba untuk menggali persoalan terkait konvensi dengan cara menelaah teoriteori, konsep-konsep, asas-asas hukum serta peraturan perundang-undangan yang berhubungan dengan penelitian ini.

\section{Pembahasan}

Convention atau lebih dikenal dengan istilah constitutional convention, yang diteliti lebih dalam oleh Dicey seorang sarjana Inggris sebagaimana dikutip oleh Dahlan Thaib, ${ }^{6}$ berarti rules for determining the mode in which the discretionary powers of the crown (or of the ministers as servants of the crown) ought to be exercise. ${ }^{7}$ Suatu konvensi ketatanegaraan harus memenuhi ciri-ciri sebagai berikut; Konvensi ketatanegaraan itu berkenaan dengan hal-hal dalam bidang ketatanegaraan; Kemudian konvensi ketatanegaraan tumbuh, berlaku, diikuti dan dihormati dalam praktik penyelenggaraan negara; serta Konvensi sebagai bagian dari konstitusi, apabila ada pelanggaraan terhadapnya tak dapat diadili oleh badan pengadilan. ${ }^{8}$

Sejak era kemerdekaan Indonesia, konvensi menjadi hal lumrah yang terjadi dalam sistem ketatatanegaraan Indonesia. Hal itu disebabkan belum adanya tradisi untuk mencantumkan segala sesuatu dalam peraturan perundangundangan. Menurut Ismail Sunny hal ini disebabkan adanya Express agreement (persetujuan yang dinyatakan) antara sejumlah elit, bak itu eksekutif maupun legislatif sehingga konvensi tersebut merasa tidak perlu dinormakan dalam bentuk peraturan perundang-undangan. ${ }^{9}$

Untuk dianggap sebagai konvensi, suatu norma tidak tertulis harus memenuhi persyaratan-persyaratan yang jelas. Apabila syarat terciptanya kebiasaan itu diberlakukan pada kebiasaan ketatanegaraan, maka konvensi ketatanegaraan sebagai kebiasaan akan terbentuk melalui proses yang relatif lama. Sebagai kebiasaan, konvensi ketatanegaraan harus memenuhi beberapa persyaratan antara lain, (1) harus ada preseden yang timbul berkalikali; (2) preseden yang timbul karena adanya sebab secara umum dapat dimengerti atau

5 Johnny Ibrahim,Teori dan Metodologi Penelitian Hukum Normatif, (Malang:Bayumedia Publishing, 2006), hlm. 295.

6 Dahlan Thaib dkk, Teori dan Hukum Konstitusi, (Jakarta: PT Grafindo Persada, 2006), hlm.12.

7 A.V. Dicey, An Introduction to the study of the law of the constitution, (London: EL and S and Macmillas, 1967), hlm. 422.

8 Weldy Agiwinata, "Konvensi Ketatanegaraan Sebagai Batu Uji Dalam Pengujian Undang-Undang Di Mahkamah Konstitusi," Yuridika (2014):153.

9 I Gede Yusa, Hukum Tata Negara Paasca Perubahan UUD NRI 1945, (Malang:Setara Press, 2016), hlm. 48. 
dapat diterima; dan (3) preseden itu karena adanya kondisi politik yang ada. ${ }^{10}$

Syarat pertama, merupakan hakikat kebiasaan itu sendiri, sebab tidak ada kebiasaan yang tidak dilakukan secara berulang-ulang. Syarat kedua, sama dengan "opinion necessitatis" atau keyakinan akan kewajiban (hukum) yang berlaku di Eropa Kontinental. Keyakinan sebagai kewajiban hukum ini idealnya tidak hanya dirasakan oleh seseorang atau golongan tertentu, tetapi oleh sebagian terbesar warga negara. Syarat ketiga, dibutuhkan karena tuntutan kondisi politik dalam skala yang luas. Karena kehidupan politik menuntut dibentuknya tindakan baru sebagai awal terciptanya konvensi ketatanegaraan atau tetap mempertahankan tradisi ketatanegaraan lama yang dianggap selama ini sudah menjadi konvensi ketatanegaraan. ${ }^{11}$

\section{Konvensi di Indonesia}

Berkenaan dengan pengertian konvensi ketatanegaraan menurut sistem di Indonesia, Bagir Manan menjelaskan Konvensiatau (hukum) kebiasaan ketatanegaraan adalah (hukum) yang tumbuh dalam praktik penyelenggaraan negara, melengkapi, menyempurnakan, menghidupkan (mendinamisasi), kaidah-kaidah hukum perundang-undangan atau hukum adat ketatanegaraan. ${ }^{12}$

Hal ini disepakati pula oleh Donald A. Rumokoy, yang dalam pendapatnya mengatakan bahwa konvensi ketatanegaraan adalah segenap kebiasaan atau tindakan ketatanegaraan yang bersifat mendasar, yang dilakukan dalam menyelenggarakan aktivitas bernegara oleh alat-alat kelengkapan negara, dan belum diatur dalam konstitusi serta peraturan ketatanegaraan lainnya, dengan maksud untuk melengkapi ketentuan-ketentuan ketatanegaraan atau sebagai faktor pendinamisasi pelaksanaan konstitusi. ${ }^{13}$

Sebelum dan sesudah era reformasi, terdapat beberapa konvensi ketatanegaraan di Indonesia yang dapat diinventarisasi oleh penulis:

1. Upacara Bendera Setiap Tanggal 17 Agustus;

2. Pidato Presiden Tanggal 16 Agustus;

3. Pemilihan Menteri dan Jabatan tertentu oleh Presiden;

4. Foto Presiden dan Wakil Presiden di Kantor Pemerintahan;

5. Pemberian Grasi, Amnesti, Abolisi, atau Rehabilitasi;

6. Program 100 Hari Kerja;

7. Menteri Non Departemen;

8. Presiden RI Menjelaskan tentang RAPBN (Rancangan Anggaran Pendapatan Belanja Negara) Kepada DPR;

9. Pengambilan Keputusan oleh MPR (Majelis Permusyawaratan Rakyat).

Semua praktek ketatanegaraan di atas tidak diatur dalam peraturan perundang-undangan, dan mengacu pada asas legalitas apabila tindakan tersebut dilanggar maka tidak akan

Weldy Agawinata, Op.Cit, hal.154.

Ibid.

Bagir Manan, Konvensi Ketatanegaraan, (Bandung: Armico,1987), hlm. 1.

Weldy Agiwinata, Op.Cit, Hal.154 
ada juga konsekuensi hukum yang terjadi. ${ }^{14}$ Dengan kondisi sebagaimana Penulis sebutkan diatas, apakah implikasi yang terjadi apabila tradisi ketatanegaraan tersebut ditiadakan?

Dalam negara yang menganut asas common law, praktek yang didasarkan pada tradisi adalah sesuatu yang lumrah dalam kehidupan bernegara. Hal ini berbeda dengan negara yang menganut asas civil law, tradisi ketatanegaraan masih ada meskipun sebagian besar sudah dinormakan dalam bentuk peraturan perundang-undangan. ${ }^{15}$

Berdasarkan inventarisasi konvensi ketatanegaraan yang sudah ada sejak era reformasi, dapat dilihat bahwa tradisi yang sebelumnya berbentuk hukum tidak tertulis perlahan-lahan mulai diformalkan dalam norma tertulis.

a. Pelaksanaan Upacara Bendera setiap tanggal

\section{Agustus}

Upacara bendera setiap tanggal 17 Agustus merupakan agenda rutin ketatanegaraan di seluruh wilayah Indonesia. Pada awalnya tradisi ini dilandasi oleh konvensi atau kebiasaan ketatanegaraan di seluruh Indonesia. Namun, sejalan dengan waktu, tradisi ini diformalkan dalam sejumlah peraturan perundangundangan. Formalisasi itu dimulai dari munculnya pasal terkait kewajiban pengibaran bendera merah putih dalam Pasal 7 ayat (3) Undang-Undang Nomor 24 Tahun 2009. ${ }^{16}$
Padahal apabila kita melihat ke belakang, di era orde baru tidak ada undang-undang yang mengatur praktek tersebut, akan tetapi hanya mendasarkan pada instruksi semata. Praktek pengibaran bendera merah-putih pada tanggal 17 Agustus berjalan serentak dan sangat sedikit ada pihak yang tidak tunduk dan taat pada instruksi tersebut. Bandingkan dengan kondisi saat ini, meskipun dinarasikan dalam bentuk peraturan perundang-undangan, masih banyak pihak yang tidak tunduk serta taat pada ketentuan tersebut.

Selain kewajiban pengibaran bendera merah putih, terdapat pula undang-undang yang mengatur terkait upacara kemerdekaan, yaitu Pasal 16 Undang-Undang Nomor 9 Tahun 2010 tentang Keprotokolan yang berbunyi:

Upacara bendera hanya dapat dilaksanakan untuk Acara Kenegaraan atau Acara Resmi:

a. Hari Ulang Tahun Proklamasi Kemerdekaan Republik Indonesia;

b. hari besar nasional;

c. hari ulang tahun lahirnya lembaga negara;

d. hari ulang tahun lahirnya instansi pemerintah; dan

e. hari ulang tahun lahirnya provinsi dan kabupaten/kota.

Ketentuan di atas, memberikan legitimasi yang kuat bagi pemerintah untuk menyelenggarakan upacara setiap tanggal 17 Agustus. Undang-Undang Nomor 9 tahun 2010 tentang Keprotokolan bersifat komplementer dengan Undang-Undang Nomor 24 tahun 2009

14 Arti penting asas legalitas sebagai suatu prinsip ketatanegaraan di mana rakyat harus mendapatkan perlindungan hukum. Seperti dikemukakan Oemar Seno Adji dengan "Prinsip Legality" merupakan karakteristik yang essentieel, baik ia di kemukakan oleh Rule of Law konsep, maupun oleh faham rechstaat dahulu, maupun oleh konsep socialist. Oleh karena itu rumusan asas legalitas yang dirumuskan di dalam bahasa Latin: Nulla poena sine lege, nulla poena sine crimine, nullum crimen sine poena legali" pada pengaplikasian awal lebih menekankan perbuatan-perbuatan yang dilarang itu di dalam Undang-undang. Lihat di Hwian Christianto, "Pembaharuan Makna Asas Legalitas," Jurnal Hukum dan Pembangunan (2009) : 354.

15 Mahfud MD, Konstitusi dan Hukum dalam Kntroversi Isu, (Jakarta:Rajawali Press, 2012),hlm.256

16 Undang-Undang Nomor 24 Tahun 2009 tentang Bendera 
tentang Bendera. Oleh karena itulah meskipun sejak era orde baru sudah ada pelaksanaan upacara bendera setiap tanggal 17 Agustus, saat ini hal ini menjadi tradisi rutin yang dinormakan serta dilaksanakan disetiap kantor atau instansi pemerintahan diseluruh wilayah Indonesia.

Tidak cukup hanya di instansi pemerintahan, penormaan kebiasaan ketatanegaraan ini di lembaga pendidikan juga diatur dalam peraturan perundangan-undangan, yaitu Permendiknas Nomor 39 Tahun 2008 tentang Pembinaan kesiswaan. Dengan tujuan untuk pembinaan kesiswaaan yang sasarannya meliputi siswa TK/TKLB, SD/SDLB dan SMA/ SMK/SMALB yang dilaksanakan melalui kegiatan ekstrakurikuler dan kokurikuler, maka dibentuk 10 materi pembinaan yang butir nomor 3 adalah membentuk kepribadian unggul, wawasan kebangsaan dan bela negara (pasal 3 butir 2c).Pada lampiran yang menjelaskan jenis kegiatan pembinaan kesiswaan butir nomor 3 dijelaskan Pembinaan kepribadian unggul, wawasan kebangsaan dan bela negara antara lain dilakukan dengan melaksakan upacara bendera pada hari senin dan/atau sabtu, serta hari-hari besar nasional.

\section{b. Pidato Presiden Tanggal 16 Agustus}

Sejak era orde baru, Presiden Soeharto merupakan pelopor tradisi kenegaraan dimana Presiden menyampaikan pidatonya di depan seluruh anggota MPR setiap tanggal 16 Agustus. Pidato kenegaraan ini pada dasarnya tidak relevan dengan sistem pemerintahan Indonesia yang menganut sistem pemerintahan presidensiil, yaitu Presiden bertanggung jawab langsung kepada rakyat bukan kepada parlemen. Akan tetapi tradisi itu berjalan secara rutin meskipun tidak ada dasar hukumnya.
Akan tetapi sejak tahun 2010, tradisi ketatanegaraan ini diformalkan dalam bentuk peraturan perundang-undangan, yaitu terdapat pada Undang-Undang Nomor 27 Tahun 2009 tentang Majelis Permusyawaratan Rakyat, Dewan Perwakilan Rakyat, Dewan Perwakilan Daerah, dan Dewan Perwakilan Rakyat Daerah (MD3). ${ }^{17}$

Merujuk pada Undang-Undang tersebut, Presiden melakukan 2 (dua) kali pidato dalam satu hari tanggal 16 Agustus. Pidato pertama adalah Pidato Kenegaraan menyambut Hari Ulang Tahun Proklamasi Kemerdekaan RI dan pidato kedua adalah Pidato Penyampaian RUU tentang APBN. Pidato Penyampaian RUU APBN dilakukan di hadapan DPR, sedangkan Pidato Kenegaraan Hari Ulang Tahun Proklamasi Kemerdekaan RI dilakukan dalam Sidang Bersama (joint session) antara DPR dengan DPD. Sidang bersama DPR-DPD diatur dalam Peraturan Bersama DPR dan DPD yang disahkan pada tanggal 3 Agustus 2010, dan penyelenggaranya bergantian antara DPR dan DPD. Di Pasal 228 Undang-Undang Nomor 17 Tahun 2014, praktek diatur lebih tegas dan mendetil.

Adanya Undang-Undang MD3 yang meformalkan ketentuan terkait tradisi ketatanegaran yang dilakukan oleh Presiden setiap tanggal 16 Agustus, secara otomatis mengubah konvensi ketatanegaraan sejak era orde baru ini menjadi hukum tertulis.

c. Pemilihan Menteri dan Jabatan tertentu oleh Presiden

Dalam sistem pemerintahan presidensiil kewenangan Presiden untuk mengangkat Menteri dan jabatan lain setingkat Menteri

17 Undang-Undang Nomor 27 Tahun 2009 tentang MD3 
mutlak menjadi kewenangan Presiden. ${ }^{18}$ Meskipun mempunyai kewenangan mutlak dalam hal pengangkatan, namun dalam prakteknya Presiden kerap kali melibatkan lembaga lain seperti KPK atau Kejaksaan atau membentuk Tim Seleksi yang dibentuk untuk melakukan seleksi dalam memilih pejabat tertentu yang mempunyai kelayakan dan kecakapan sebagai contoh pengangkatan hakim Mahkamah Konstitusi.

Preseden itu sempat tidak diikuti oleh Presiden Susilo Bambang Yudhoyono (SBY) dalam pengangkatan Patrialis Akbar dan Maria Farida sebagai Hakim Mahkamah Konstitusi. Presiden SBY pada waktu itu mengeluarkan Keputusan Presiden Nomor 87 Tahun 2013 tentang Pengangkatan Patrialis Akbar dan Maria Farida sebagai Hakim Mahkamah Konstitusi (MK) tanpa melalui proses uji kompetisi dan kelayakan (fit and proper test). ${ }^{19}$ Pada akhirnya Kepres itu digugat ke PTUN, dan sempat dicabut oleh Putusan PTUN. Akan tetapi, Mahkamah Agung memutuskan bahwa Keputusan Presiden SBY yang mengangkat Patrialis Akbar dan Maria Farida tanpa melalui uji kompetisi dan kompetensi tidak melanggar undang-undang.

Meskipun sudah menjadi tradisi pengangkatan Hakim MK melalui tim ahli, ketika Presiden SBY melanggar tradisi itu, Pembuat undang-undang kemudian menormakan itu di dalam peraturan perundang-undangan, yaitu Pasal 18 A Undang-Undang Nomor 4 Tahun 2014 Tentang Penetapan Peraturan Pemerintah Pengganti Undang-Undang Nomor 1 Tahun 2013 Tentang Perubahan Kedua Atas Undang-Undang
Nomor 24 Tahun 2003 Tentang Mahkamah Konstitusi Menjadi Undang-Undang.

Sejak adanya ketentuan ini, tradisi ketatanegaraan yang mana pengangkatan Hakim MK melalui Tim Seleksi yang sempat dilanggar di era Pemerintahan SBY menjadi norma terikat yang harus ditaati oleh setiap Presiden RI. Begitu pula dalam hal pengangkatan Menteri, tradisi yang muncul saat ini adalah ketika Presiden hendak mengangkat Menteri maka dia akan melibatkan KPK dan PPATK untuk melihat bagaimana profil calon menteri tersebut. Akan tetapi tradisi ini baru berjalan beberapa waktu, sehingga saat ini tradisi ini masih berjalan sebagai salah satu konvensi dalam sistem ketatanegaraan Indonesia.

d. Foto Presiden dan Wakil Presiden di Kantor Pemerintahan

Apabila mengacu pada Pasal 51 jo. Pasal 53 Undang-Undang Nomor 24 Tahun 2009 tentang Bendera, Bahasa, dan Lambang Negara, Serta Lagu Kebangsaan yang wajib dipasang di Gedung dan/atau Kantor Lembaga Negara atau Instansi Pemerintah adalah Lambang Negara yaitu Garuda Pancasila dengan semboyan Bhinneka Tunggal Ika. Namun apabila kita melihat pasal 55 undang-undang tersebut, secara implisit terdapat perintah untuk pemasangan gambar wakil Presiden di antara lambang negara.

Undang-undang ini tidak mengatur secara tegas terkait kewajiban pemasangan foto presiden dan wakil presiden di setiap instansi pemerintahan. Hanya saja sebagai sebuah konvensi, praktik ini sudah dilakukan sejak lama sehingga saat tidak ada dasar hukum

\footnotetext{
18 Jimly Asshidiqie, Pokok-Pokok Hukum Tata Negara Indonesia, (Jakarta:PT Bhuana Ilmu Populer,2007), hlm.337.

19 Kompas, "Presiden Jilat Ludah Sendiri dengan Angkat Patrialis Jadi Hakim MK," Kompas, https://nasional. kompas.com/read/2013/08/11/1739017/Presiden.Jilat.Ludah.Sendiri.dengan.Angkat.Patrialis.Jadi.Hakim.MK (diakses 27 Januari 2019)
} 
yang mengaturnya, tidak ada seorangpun yang mempermasalahkanya. Apalagi saat ini ada aturan yang mengatur hal tersebut secara implisit, oleh karena itu sebagai sebuah praktek hal ini sudah dinormakan dalam aturan perundang-undangan.

e. Pemberian Grasi, Amnesti, Abolisi, atau Rehabilitasi

Pemberian grasi, amnesti, abolisi atau rehabilitasi sejak era orde baru merupakan kewenangan mutlak Presiden sebagai kepala negara meskipun dalam prakteknya Presiden selalu meminta pertimbangan kepada DPR atau Mahkamah Agung. Sebelum era amandemen UUD 1945, berdasarkan ketentuan dalam Pasal 14 UUD 1945, Presiden memegang kekuasaan absolut terhadap pemberian grasi, rehabilitasi, amnesti dan abolisi. Selain keberadaan konstitusi sebagai dasar hukum, pada era sebelum amandemen konstitusi juga terdapat Peraturan Pemerintah Nomor 7 Tahun 1947, Peraturan Pemerintah Nomor 67 Tahun 1948 dan Undang-Undang Nomor 3 Tahun 1950 tentang Permohonan Grasi.

Ketiga peraturan perundang-undangan tersebut hanya mengatur terkait tata cara mengajukan permohonan grasi serta siapa saja yang berhak mengajukan grasi, begitupula dengan rehabilitasi, amnesti dan abolisi ketigatiganya pada era sebelum amandemen UUD 1945 mutlak menjadi kewenangan Presiden dan tidak ada kewajiban untuk mendapatkan pertimbangan ataukah persetujuan dari Mahkamah Agung ataupun DPR. Pada tahun 1973, berdasarkan TAP MPR No.VI/MPR/1973 pasal 11 ayat 3, MPR kemudian menormakan kewenangan Mahkamah Agung terkait dengan pemberian nasehat hukum kepada Presiden untuk pemberian/penolakan grasi, meskipun sebelum ada norma tersebut pada prakteknya Presiden selalu meminta pertimbangan kepada Mahkamah Agung. Tradisi itu kemudian di normakan lebih tegas dalam Pasal 14 UUD NRI 1945 setelah amandemen, apabila Presiden ingin memberikan grasi, rehabilitasi, amnesti ataupun abolisi, maka Presiden wajib meminta pertimbangan DPR atau Mahkamah Agung.

f. Program 100 Hari Kerja

Program 100 hari kerja merupakan tradisi ketatanegaraan yang kita bangun sejak era reformasi. Sebenarnya hal ini pada awalnya adalah upaya masyarakat untuk mengukur indikator keberhasilan Presiden baru, yaitu Presiden BJ Habibie, KH Abdurrahman Wahid dan Megawati Soekarnoputri. Namun sejak Pilpres 2004, Presiden SBY pertama kali memperkenalkan program 100 hari kerja yaitu Pemberantasan mafia hukum, Revitalisasi industri pertanian, Penangggulangan terorisme, Kesediaan listrik, Peningkatan produksi dan ketahanan pangan, Revitalisasi pabrik pupuk dan gula, Penataan tanah dan tata ruang, Peningkatan infrastruktur, Peningkatan pinjaman usaha mikro usaha kecil dan usaha menengah, Pendanaan, Penanggulangan perubahan iklim dan lingkungan, Reformasi kesehatan, Reformasi pendidikan, Kesiagaan dalam penanggulangan bencana, dan Koordinasi erat pemerintah pusat dan daerah. ${ }^{20}$ Setelah tahun 2004, Setiap calon presiden pasti punya tradisi untuk melakukan pencapaian tertentu selama 100 hari kerja. Hingga saat ini, kebiasaan

20 Viva, "Ini 15 Program Pilihan SBY untuk 100 Hari, "Viva, https://www.viva.co.id/amp/berita/nasional/103225ini-15-program-pilihan-sby-untuk-100-hari (diakses 22 Februari 2019) 
ini masih berjalan dan belum dinormakan dalam peraturan perundang-undangan.

\section{g. Menteri Non Departemen}

Pengangkatan Menteri non departemen bersamaan dengan pengangkatan Menteri merupakan tradisi ketatanegaraan yang sudah berlangsung sejak era orde baru. Biasanya jabatan yang diangkat secara bersamaan dengan Menteri adalah Jaksa Agung dan Gubernur BI. Pelaksanaan tradisi ketatanegaraan ini berhenti di era kepemimpinan Presiden Susilo Bambang Yudhoyono. Presiden SBY pada waktu itu memutuskan untuk tidak mengangkat lagi Jaksa Agung pada periode II kepemimpinannya sebagai Presiden. Presiden SBY tetap membiarkan Jaksa Agung Hendarman Supandji menduduki jabatannya sebagai Hakim Agung tanpa melantiknya kembali.

Pada pasal 19 Undang-Undang Nomor 16 Tahun 2004 tentang Kejaksaan Agung Republik Indonesia, mengatakan bahwa Jaksa Agung adalah pejabat negara sehingga diangkat dan diberhentikan oleh Presiden. Sehingga Jaksa Agung merupakan bagian dari Kabinet yang usia jabatannya sama dengan usia jabatan Presiden yang memilihnya, yaitu lima tahun.

Mahkamah Konstitusi sendiri menyatakan bahwa pasal terkait ketentuan ini adalah konstitusional bersyarat (Conditionally Constitutional). Akan tetapi sebagai sebuah tradisi ketatanegaraan sejak era orde baru, tindakan Presiden SBY yang memutuskan untuk tidak melantik lagi Jaksa Agung untuk periode kedua karena tidak ada ketentuannya merupakan kesalahan politik. Saat ini tradisi ini masih tetap berjalan namun sudah dinormakan secara tertulis dalam peraturan perundanganundangan, jabatan Jaksa Agung selalu diangkat dan dilantik setiap 5 tahun sekali pada pergantian pemerintahan. h. Presiden RI Menjelaskan tentang RAPBN (Rancangan Anggaran Pendapatan Belanja Negara) Kepada DPR

Salah satu tradisi ketatanegaraan di Indonesia adalah setiap tanggal 16 Agustus Presiden menyampaikan tentang RUU APBN, baik perubahannya atau untuk ke depannya. Penyampaian penjelasan itu dilakukan di depan anggota DPR dalam bentuk sidang paripurna bersamaan dengan pidato kenegaraan.

Pada awalnya hal ini tidak diatur secara formal dalam peraturan perundang-undangan. Hingga saat ini pun yang diatur terkait pidato tangal 16 Agustus adalah pidato kenegaraan, dan tidak mengatur terkait detil hal yang dibicarakan dalam pidato kenegaraan tersebut. Akan tetapi penjelasan Presiden terkait UU APBN dan APBN-Perubahan selalu dilakukan pada tanggal 16 Agustus dan menjadi tradisi ketatanegaraan Indonesia hingga saat ini.

i. Pengambilan Keputusan oleh MPR (Majelis Permusyawaratan Rakyat)

Proses pengambilan keputusan MPR yang dilakukan secara musyawarah merupakan tradisi kenegaraan Indonesia sejak era orde baru. Padahal apabila mengacu pada UUD NRI 1945 sebelum amandemen, di dalamnya tidak ada satupun kata pengambilan keputusan secara musyawarah mufakat. Akan tetapi karena pada waktu itu sudah menjadi tradisi ketatanegaraan yang sudah ada sejak era orde baru, tradisi ini masih berjalan. Satu-satunya dasar hukum yang pernah mengatur terkait konsep musyawarah mufakat adalah. TAP MPR No. II/MPR/1999 yang pada pasal 83 mengatur terkait syarat sahnya pengambilan keputusan melalui musyawarah, yaitu apabila diambil dalam suatu rapat yang daftar hadirnya telah ditandatangani lebih dari separuh jumlah 
anggota rapat yang mencerminkan setiap fraksi kecuali dalam penetapan GBHN.

\section{Konvensi dalam Sistem Hukum Nasional}

Dari paparan sebelumnya, dapat terlihat bahwakonvensisebagaisalahsatusumberhukum ketatanegaraan jumlahnya semakin berkurang. Hal ini disebabkan adanya kecenderungan mengformalkan semua tradisi ketatanegaraan dalam bentuk hukum tertulis. Keberadaan Undang-Undang Nomor 12 Tahun 2011 tentang Pembentukan Peraturan Perundang-undangan yang didalamnya terdapat hierarki peraturan perundang-undangan di Indonesia menciptakan kompleksitas persoalan terkait posisi konvensi, karena dalam penjelasannya terdapat semangat untuk memformalkan semua peraturan perundang-undangan menjadi norma tertulis agar sesuai dengan sistem hukum nasional. ${ }^{21}$ Adanya Undang-Undang inilah yang menjadi salah satu dasar formalisasi konvensi dalam bentuk hukum tertulis.

Sebagai sebuah sumber hukum, keberadaan konvensi yang tidakjelas pengaturannya menjadi persoalan dalam ketatanegaraan Indonesia. Sebagaimana yang diketahui terdapat 6 sumber hukum di Indonesia, yaitu:

a. Sumber Hukum Materiil, yaitu sumber dari segala sumber hukum, dalam konteks negara Indonesia adalah Pancasila.

b. Sumber Hukum Formil, berdasarkan undangundang nomor 12 tahun 2011, sumber hukum formil di Indonesia adalah: ${ }^{22}$

1) Undang-Undang Dasar 1945 (UUD 1945)
2) Ketetapan MPR (TAP MPR)

3) Undang-Undang (UU)/Peraturan Pemerintah Pengganti Undang-Undang (PERPU).

4) Peraturan Pemerintah (PP).

5) Peraturan Presiden (PERPRES).

6) Peraturan Daerah (PERDA).

a) PERDA provinsi

b) PERDA Kota/Kabupaten

c) Peraturan Desa.

c. Traktat, yaitu perjanjian internasional contoh Traktat ASEAN, PBB, dll

d. Yurisprudensi, yaitu putusan pengadilan terdahulu;

e. Pendapat Ahli; dan

f. Konvensi.

Sebagai salah satu sumber hukum yang mempunyai karakteristik tidak tertulis, konvensi yang sudah diformalkan dalam bentuk peraturan perundang-undangan secara otomatis tidak termasuk dalam konvensi ketatanegaraan. Padahal sebagai salah satu sumber hukum, konvensi merupakan tradisi ketatanegaraan yang sudah ada dan disepakati bersama sehingga tidak perlu lagi dinormakan dalam peraturan perundang-undangan. Kondisi ini bisa menciptakan perspektif bahwa hukum tidak akan berlaku kalau tidak ada norma tertulis yang mengaturnya, dan secara tidak langsung serta perlahan demi perlahan akan menegasikan konvensi sebagai salah satu sumber hukum bangsa Indonesia.

Perkembangan konvensi di negara lain misalnya Amerika Serikat (AS), sebagai salah satu

21 Berdasarkan Pasal 1 ayat (2) Undang-Undang Nomor 2 Tahun 2011, definisi Peraturan Perundang-undangan adalah peraturan tertulis yang memuat norma hukum yang mengikat secara umum dan dibentuk atau ditetapkan oleh lembaga negara atau pejabat yang berwenang melalui prosedur yang ditetapkan dalam Peraturan Perundang-undangan.

22 Undang-Undang Nomor 12 Tahun 2011 tentang Pembentukan Peraturan Perundang-undangan 


\section{RUECHTSVINDING}

Media Pembinaan Hukum Nasional

negara yang menganut sistem hukum common law menunjukkan perbedaan yang menarik. Negara AS merupakan salah satu negara demokrasi yang mana justru dalam tradisi ketatanegaraannya dipenuhi oleh konvensikonvensi (kebiasaan). Secara sederhana, hampir semua proses ketatanegaraan di Amerika Serikat tidak ada norma kongkret yang mengaturnya. Mulai dari proses pemilu pendahuluan (primary election), lalu ajang debat kandidat calon presiden, pidato kemenangan (victory speech), pidato pengakuan kekalahan (concession speech), hingga Presiden berbicara di depan seluruh kekuasaan legislatif dan yudikatif yang dikenal dengan state of the union. Semua tradisi itu tidak terdapat aturan yang tertulis, akan tetapi sampai saat ini praktek itu masih berjalan dan tidak timbul persoalan. Hal ini pun terjadi di negara lainnya yang mana menempatkan sistem common law sebagai sistem hukumnya, seperti Inggris ataupun Australia.

Begitupula di negara dengan sistem hukum civil law seperti Belanda, masih terdapat banyak tradisi ketatanegaraan yang sampai sekarang masih dipertahankan keberadaannya dan tidak diatur dalam norma tertulis, seperti jabatan Perdana Menteri yang secara otomatis akan dijabat oleh Pimpinan tertinggi dari Partai yang memperoleh suara terbesar dalam pemilihan umum.

Melihat pelaksanaan konvensi di Amerika Serikat dan Belanda terlihat bahwa eksistensi konvensi sejatinya tidak dibatasi oleh sistem hukum. Di negara yang terbangun dengan tradisi common law seperti Amerika Serikat, hampir semua praktik ketatanegaraan tidak dinormakan dalam peraturan yang tertulis dan dibiarkan tetap ada sebagai bagian dari tradisi ketatanegaraan, namun ketika ada pelanggaran terhadap tradisi tersebut memang
Volume 8, Nomor 1, April 2019

ada kecenderungan untuk menormakan tradisi tersebut dalam peraturan yang tertulis. Hal itu pernah terjadi dalam kasus terpilihnya Presiden Franklin D.Rosevelt untuk ketiga kalinya pada tahun 1940. Padahal tradisi ketatanegaraan di Amerika Serikat Presiden hanya menjabat sekali dan dapat dipilih kembali untuk satu masa jabatan. Pada tahun 1947, Kongres kemudian melakukan amandemen dan menormakan tradisi ketatanegaraan tersebut dalam konstitusi. Sementara itu Belanda yang menganut sistem civil law, tradisi ketatanegaraan yang sudah ada juga tidak pernah dipersoalkan, dan hingga saat ini praktik itu tidak dinormakan dalam aturan tertulis.

Saat ini ada beberapa konvensi ketatanegaraan Indonesia yang masih bertahan salah satunya adalah pengangkatan pejabat setingkat Menteri setiap 5 tahun sekali. Khusus untuk pengangkatan pejabat setingkat Menteri bahkan sudah diuji konstitusionalitasnya di Mahkamah Konstitusi dengan putusan MK adalah Konstitusional bersyarat. Hal ini mengindikasikan bahwa MK sejatinya juga melihat bahwa posisi konvensi dalam sistem ketatanegaraan Indonesia masih simpang siur, apakah konstitusional ataukah inkonstitusional. Oleh karena itulah tindakan pemerintah untuk menormakan segala tradisi ketatanegaraan dalam norma tertulis sejatinya merupakan upaya untuk menghapus konvensi sebagai salah satu sumber hukum tata negara Indonesia. Dengan merujuk praktik konvensi yang ada di Amerika Serikat dan Belanda, sejatinya konvensi tidak mengenal batas terkait negara dengan sistem hukum civil law ataukah common law. Keberadaan konvensi yang disepakati bersama sebagai tradisi ketatanegaraan akan membuat Indonesia tidak terjebak dalam problematika banjirnya aturan di masyarakat (Over regulated 
society). Ketika segala sesuatu harus diatur dengan norma tertulis, maka ketika ada dinamika masyarakat yang berubah, Pemerintah terlihat dalam posisi yang dilematis. Sebagai contoh aturan yang sangat mendetail dalam Pasal 344 ayat (2) Undang-Undang Nomor 7 tahun 2017 tentang Pemilu yang mengatur jumlah kertas suara yang dicetak sama dengan jumlah DPT ditambah 2\% dari jumlah DPT sebagai cadangan. Ketentuan ini sangat detail, yang akhirnya ketika ada potensi penumpukan suara di beberapa TPS, KPU tidak berani menambah kertas suara karena takut melanggar UU. Oleh karena itulah keberadaan konvensi masih diperlukan di Indonesia, agar tidak semua hal harus diatur dengan norma tertulis.

Untuk memberikan kepastian hukum terkait dengan posisi konvensi, Pembuat undang-undang harus menempatkan konvensi sebagai salah satu sumber hukum yang diakui dalam Undang-Undang tentang Pembentukan Peraturan Perundang-undangan. Dengan memberikan kepastian hukum bagi keberadaan konvensi sebagai norma tidak tertulis, maka untuk kedepannya tidak semua praktik ketatanegaraan harus diatur dengan norma tertulis.

\section{Penutup}

Sebagai salah satu sumber hukum, konvensi semakin lama semakin tergerus oleh arus formalisasi undang-undang. Sebagai tradisi ketatanegaraan di Indonesia, konvensi selayaknya tetap dipertahankan keberadaannya. Selain masih dipertanyakan terkait dengan konstitusionalitasnya, praktik ini juga mencegah Indonesia terjebak ke dalam kondisi over regulated society, dimana segala sesuatu harus diatur dengan hukum tertulis secara mendetail.
Semakin hilangnya konvensi sebagai salah satu sumber hukum harus dipikirkan oleh para pembuat undang-undang, karena konvensi adalah tradisi bernegara yang tidak bisa dihilangkan dan dinegasikan dengan alasan tidak adanya aturan tertulis. Para pembuat undang-undang harus mulai memikirkan hal ini, bagaimana membuat suatu peraturan untuk mengatur keberadaan konvensi, bukan justru mengformalkannya dalam norma tertulis, akan tetapi negara bisa menempatkan konvensi sebagai salah satu sumber hukum dalam undang-undang tentang pembentukan peraturan perundang-undangan. Pengakuan konvensi sebagai salah satu sumber hukum yang diakui posisinya dalam sistem ketatanegaraan Indonesia, akan membuat nihilnya upaya formalisasi konvensi dalam norma tertulis. Dan untuk kedepannya tidak muncul lagi perdebatan terkait konstitusionalitas suatu tradisi ketatanegaraan, sebagaimana dengan yang terjadi di negara-negara dengan sistem hukum common law.

\section{Daftar Pustaka}

\section{Buku}

Asshidiqie, Jimly, Pokok-Pokok Hukum Tata Negara Indonesia (PT Bhuana Ilmu Populer: Jakarta, 2007)

Dicey, A.V, An Introduction to the study of the law of the constitution (EL and S and Macmillas:London, 1967)

Friedman, Lawrence, American Law (London: W.W. Norton \& Company, 1984)

MD, Mahfud, Konstitusi dan Hukum dalam Kontroversi Isu (Rajawali Press: Jakarta, 2012)

Thaib, Dahlan dkk, Teori dan Hukum Konstitusi (PT Grafindo Persada:Jakarta, 2006)

Yusa, I Gede, Hukum Tata Negara Paasca Perubahan UUD NRI 1945 (Setara Press: Malang, 2016) 


\section{Makalah/Artikel/Prosiding/Hasil Penelitian}

H. Mustaghfirin, "Sistem Hukum Barat, Sistem Hukum Adat, dan Sistem Hukum Islam Menuju Sebagai Sistem Hukum Nasional Sebuah Ide Yang Harmoni", Jurnal Dinamika Hukum (2011)

Hwian Christianto, "Pembaharuan Makna Asas Legalitas", Jurnal Hukum dan Pembangunan (2009)

Tri Suhendra Arbani, "Eksistensi Konvensi sebagai Sumber dan Praktek Ketatanegaraan di Indonesia", Supremasi Hukum ( 2016)
Weldy Agiwinata,"Konvensi Ketatanegaraan Sebagai Batu Uji Dalam Pengujian Undang-Undang Di Mahkamah Konstitusi”,Yuridika (2014)

\section{Internet}

Judge Peter J.Mesitte, "Common Law V. Civil Law Systems",http://web.ntpu.edu.tw/ markliu/ common_v_civil.pdf (diakses 12 Februari 2019) 
"Halaman ini dikosongkan" 